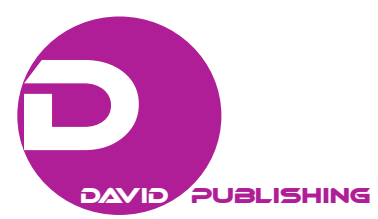

\title{
Impact of Global Financial Crises on the Indonesian Economy: An Input-Output Analysis
}

\author{
Muhammad Handry Imansyah, Suryani, Syahrituah Siregar, Muzdalifah, Hidayatullah Muttaqin \\ Lambung Mangkurat University, Banjarmasin, Indonesia
}

\begin{abstract}
The debt crisis in the European Union (EU) and the U.S. has significant potential impact on the economy of Indonesia. U.S. sub-prime mortgage crisis in 2008 has a strong impact on Indonesian economy, that Indonesia's gross domestic product (GDP) slowed down to below 5\% during 2009. Until October 2012, Indonesia's export growth is starting to grow negatively on some sectors when the crises in the EU and the U.S. have started or overall grew by $-6 \%$. Although the slowdown does not occur in all sectors, the impact spreads to other sectors as the existence of industrial linkage among sectors. The objective of the study is to look at the impact on the sector level on various indicators such as GDP (value added) and employment. Input-output analysis will be used in the simulation. Indonesia input-output table of 2005 is applied as the data base. The simulation results show that if exports decline occurs in the U.S., the economic growth will be $-0.20 \%$. Meanwhile, if it occurs in the EU, the growth of GDP will be $-0.24 \%$. If some Asian countries face the fall of demand of Indonesian export, GDP growth declines by $0.61 \%$. The fall of exports demand from some Asian countries, EU countries and the U.S. will cause the GDP growth by $-1.06 \%$. The crisis occurring in both the US and the EU has decreased export demand from those countries and region including some Asian countries. The impact to employment seemed to be minimal, only $-0.47 \%$ of total labour force.
\end{abstract}

Keyword: input-output analysis, financial crisis, GDP growth

\section{Introduction}

The world economy experienced financial turbulence again in 2010. This global financial crisis recovery seems to remain uncertain, yet Indonesia as the country which is associated with the EU and U.S. in terms of trade linkage has the potential to be adversely affected by the crises taking place in those two regions (Djaja, n.d.; Titiheruw, Soesastro, \& Atje, 2009; Basri \& Siregar, 2009). However, Indonesian exports dropped not only to the U.S. and EU, but also to Asian countries such as Japan, China, South Korea, and ASEAN (Association of Southeast Asian Nations) countries. The data showed that the growth of export to those countries and regions dropped by $5.68 \%, 1.87 \%, 5.33 \%$, and $14.43 \%$ for ASEAN, China, Japan, and South Korean, respectively.

Muhammad Handry Imansyah, Ph.D., Faculty of Economics and Business, Lambung Mangkurat University, Banjarmasin, Indonesia.

Suryani, M.A., Faculty of Economics and Business, Lambung Mangkurat University, Banjarmasin, Indonesia.

Syahrituah Siregar, M.A., Faculty of Economics and Business, Lambung Mangkurat University, Banjarmasin, Indonesia.

Muzdalifah, M.S., Faculty of Economics and Business, Lambung Mangkurat University, Banjarmasin, Indonesia.

Hidayatullah Muttaqin, M.S., Faculty of Economics and Business, Lambung Mangkurat University, Banjarmasin, Indonesia.

Correspondence concerning this article should be addressed to Muhammad Handry Imansyah, Faculty of Economics and

Business, Lambung Mangkurat University, Jl. Brigjen H. Hasan Basry, Banjarmasin-70123, Indonesia. E-mail: mhandryi@ indo.net.id. 
The type of exports commodities affects the severity of the impact to the domestic economy (Djaja, n.d.; Berkmen, Gelos, Rennhack \& Walsh, 2009). The countries that relied on manufactured export goods are more vulnerable than that of food export goods (Berkmen et al., 2009; Wie, 2012). As in Indonesia the most of export goods are manufactured goods, of course, global financial crisis affected the demand of manufactured goods in the destination countries such as EU and U.S. (Adriyanto, 2010). However, the impact of global financial crisis to Indonesia is minimal, because the exports share is lower compared to other East Asian neighbours (Wie, 2012).

The decline in trade volume is one of the major channels of transmission for countries with export of manufactures and services (Griffith-Jones \& Ocampo, 2009). It is very difficult to explain or distinguish whether the decline in Indonesia's exports in 2012 was due to financial crisis in the EU, the U.S., and other countries or other factors. Trade linkage through exports is one of the major impact of global financial crisis to Indonesia, even though the impact is relatively light (Basri \& Siregar, 2009; Patunru \& Zetha, 2010; Wie, 2012, Djaja, n.d.). According to Basri and Siregar (2009), international trade has indeed been hit worst by the global financial crisis.

Meanwhile, in the argument proposed by Berkmen et al. (2009), the global financial crisis is said to be transmitted through four broad channels: (1) trade linkages, (2) financial linkages, (3) underlying vulnerabilities and financial structure, and (4) overall policy framework. In this regard, this chapter will only discuss the impact of global financial crisis through trade linkages. It is also aimed to make simulation of the potential impact of global financial crisis on value added (GDP) and employment using an input-output analysis. Even though the method has some weaknesses, the less data requirement and adequate accuracy for short-run potential impact are the advantage of this approach.

However, to find a more convincing analysis, one requires more in-depth and specialized studies to identify the causes of decline in Indonesia's exports in 2012. In the study presented in this chapter, the decline of exports to the EU, the U.S., and other countries is assumed as a result of falling demand for goods and services for countries affected by the crisis.

\section{Impacts of EU and U.S. Financial Crises to the GDP Growth of Indonesia}

Guimarães-Filho, Hori, Miniane, and N'Diaye (2008) examined the spillovers from the U.S. to Asia using many approaches (trade and financial exposure, correlation analysis, regression analysis, model simulations, etc.) and they found that total export exposure of emerging Asia to the U.S. in 2006 was Indonesia and India for the lowest and Singapore and Malaysia for the highest. Even though the exposure of Indonesian exports to those countries is low, the impact to some extent is moderate, because some of the commodities have strong linkage to other sectors. The fall in demand in these countries was due to the decline of income as the financial crisis in the EU and the U.S. various studies have also shown that the financial crisis caused a decline in U.S. imports from other countries such as China which led to a slowing of its economic growth. Wang, Chen, and Yang (2011) explained theoretically that the international financial crisis has gradually affected China's GDP growth. It increased by only $7.7 \%$ of the GDP in the third quarter of 2009 which over the same period of 2008 reached $9.9 \%$.

Indonesian economy, since the sub-prime mortgage crisis in 2008 , has recovered from the slow-down caused by the crisis. When the sub-prime mortgage crisis of 2008 occurred, the impact was at below 5\% in 2009 when economic growth was slowing down and began to rise again in 2010. Debt crisis in the EU zone 
is initiated by Greece, and followed by Ireland, Italy, as well as Spain and Portugal. The crisis in the EU zone will also have an impact on the economy of Indonesia accordingly. Moreover, as the U.S. has not fully recovered, it has affected Indonesia's economy too. Even worse, should the crises in the Euro zone and U.S. occur together, then the impact could be greater than the sub-prime mortgage crisis in 2008 with its impact occurring in 2009. Economic growth during 2009 averaged about $4.5 \%$ and decreased about $1.5 \%$ from an average of $6 \%$ in 2008.

In 2007, sub-prime mortgage crisis in the US, which is one of the major trading partners, affected the financial sector in Indonesia through the stock market, i.e. through the fall of stock prices which started in early 2008. Then, as shown in Figure 1, the slow-down of economic growth took place in 2009. Slow-down began to appear in the fourth quarter of 2008, but it recovered in the fourth quarter of 2009.

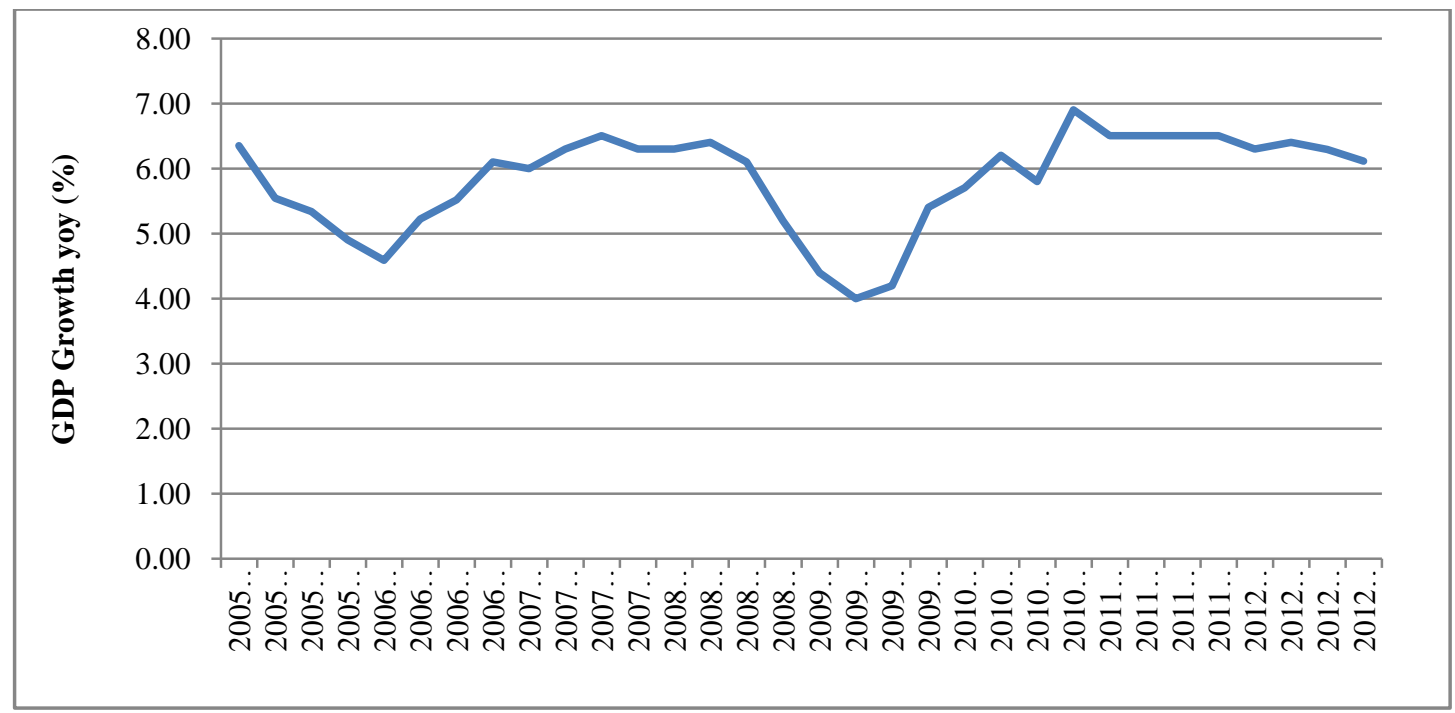

Figure 1. Quarterly GDP growth from 2005 to 2012.

Indonesian GDP growth started to recover at $6.5 \%$ in 2010 after slowing down at $4.5 \%$ of GDP growth rate. However, as the EU countries were hit by the global financial crisis, this has also negatively affected the trade linkage between the two regions. The initial impact could be seen in the GDP growth of 2012 which was slowing down slightly (Table 1). The growth rate of exports in GDP by expenditure had plunged in quarterly basis (y-o-y) by $7.80 \%, 1.90 \%, 2.21 \%$, and $0.50 \%$, in the first, second, third, and fourth quarter of 2012 respectively. Meanwhile, agriculture, mining, and manufacturing were also the sectors severely hit by the global financial crisis, which subsequently gave an impact on the GDP of Indonesia.

In the 2010, the crisis spread out to EU from the U.S. sub-prime mortgage crisis. This global financial crisis affects economic growth of the developing countries accordingly. This impact was transmitted through many broad aspects, such as trade linkage, financial linkage, and others (Berkmen et al., 2009).

The recent data shows that Indonesian exports slowed down and even reached the negative growth in some destination countries (Table 2). Export growth to the EU countries plunged by $-14.60 \%$, followed by South Korea and U.S. which dropped by $-14.43 \%$ and $-8.10 \%$, respectively. Until October 2012, Indonesia's exports seemed to be influenced by global financial crisis. Total export growth declined by $-6.88 \%$ (y-o-y). Table 2 shows that there is a negative annual growth in exports to major trading partners. The share of Indonesia's exports to ASEAN, Japan, China, and South Korea was 49\%, EU countries was $12 \%$ of total exports. 
Table 1

GDP Growth by Expenditure and by Sector (2008-2012)

\begin{tabular}{|c|c|c|c|c|c|c|c|c|c|c|c|c|c|c|c|c|c|}
\hline $\mathrm{re}$ & 2008 & $2009 Q 1$ & $2009 Q^{2}$ & $2009 Q 3$ & $2009 Q 4$ & $2010 Q 1$ & $2010 Q^{2}$ & $2010 Q 3$ & 2010Q4 & 2011Q1 & 2011Q2 & 2011Q3 & 2011Q4 & 2012Q1 & 2012Q2 & $2012 Q 3$ & $2012 Q 4$ \\
\hline House & 5.3 & 80 & 4.80 & 70 & 4.00 & 3.90 & 5.00 & 5.20 & 4.40 & 4.50 & 4.60 & 4.80 & 4.95 & 4.90 & 5.00 & 5.29 & 5.36 \\
\hline ov. Exp. & 10.4 & 19.20 & 17.00 & 10.20 & 17.00 & -8.80 & -9.00 & 3.00 & 7.30 & 3.00 & 4.50 & 2.50 & 2.90 & 5.90 & 7.00 & 2.93 & -3.34 \\
\hline vestm & 11.7 & 50 & 0 & 4.00 & 4.20 & 90 & 8.00 & 8.90 & 8.70 & 7.30 & 9.20 & 7.10 & 11.52 & 9.90 & 12.30 & 10.77 & 7.29 \\
\hline ports & 9.5 & -19.10 & -15.70 & -8.20 & 3.70 & 19.60 & 14.60 & 11.30 & 16.10 & 12.30 & 17.40 & 18.50 & 8.18 & 7.80 & 1.90 & 2.21 & 0.50 \\
\hline pports & 10 & -24.10 & -23.90 & -18.30 & 1.60 & 22.60 & 17.70 & 11.00 & 16.90 & 15.60 & 16.00 & 14.20 & 10.96 & 8.20 & 10.90 & 6.04 & 6.79 \\
\hline J & 6.1 & $T$ & 4.00 & 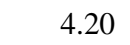 & 5.40 & 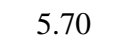 & 6.20 & 8 & 6.90 & 0 & 6.50 & 6.50 & 6.50 & 6.30 & 6.40 & 6.29 & 6.11 \\
\hline Gas & 6.5 & 4.80 & 4.40 & 4.60 & 5.80 & 6.10 & 60 & 0 & 7.40 & 6.90 & 7.00 & 6 & 7 & 0 & 90 & 6.84 & 6.73 \\
\hline y sector & 2008 & 2009Q1 & $2009 Q 2$ & $2009 Q 3$ & 2009Q4 & 2010Q1 & 2010Q2 & $2010 Q 3$ & 2010Q4 & 2011Q1 & 2011Q2 & 2011Q3 & 2011Q4 & 2012Q1 & 2012Q2 & $2012 Q 3$ & $2012 Q 4$ \\
\hline ricultu & 4.8 & 4.80 & 2.40 & 2.70 & 4.60 & 2.90 & 3.10 & 1.80 & 3.80 & 3.40 & 3.90 & 2.70 & 1.90 & 3.90 & 3.70 & 4.26 & 1.98 \\
\hline ining & 0.5 & 2.20 & 2.40 & 6.50 & 5.20 & 3.50 & 3.80 & 2.80 & 4.20 & 4.60 & 0.80 & 0.30 & -0.30 & 2.90 & 3.10 & 1.86 & 0.48 \\
\hline Ianufa & 3.7 & 1.60 & 1.50 & 1.30 & 4.20 & 3.60 & 4.30 & 4.10 & 5.30 & 5.00 & 6.10 & 6.60 & 6.70 & 5.70 & 5.40 & 5.86 & 6.24 \\
\hline ectricity & 10.9 & 11.40 & 15.40 & 14.60 & 14.00 & 7. & 4.8 & 3.20 & 4.30 & 4.20 & 3.90 & 5.20 & 5.80 & 6.10 & 5.90 & 5.56 & 7.25 \\
\hline onstruction & 7.3 & 6.30 & 6.40 & 8.80 & 8.00 & 7.30 & 7.20 & 6.40 & 6.70 & 5.30 & 7.40 & 6.40 & 7.80 & 7.30 & 7.30 & 7.45 & 7.79 \\
\hline rade & 7.2 & 0.60 & -0.10 & -0.60 & 4.20 & 9.30 & 9.60 & 8.80 & 8.40 & 7.90 & 9.60 & 10.10 & 10.20 & 8.50 & 8.90 & 8.02 & 7.80 \\
\hline ransportation & 16.7 & 16.70 & 17.50 & 18.20 & 12.20 & 11.90 & 12.90 & 13.30 & 15.50 & 13.80 & 10.70 & 9.50 & 9.20 & 10.30 & 0.10 & 10.29 & 9.63 \\
\hline nance & 8.2 & 6.30 & 5.30 & 4.90 & 3.80 & 5.50 & 6.10 & 6.30 & 6.30 & 7.30 & 6.90 & 7.00 & 6.70 & 6.30 & 7.00 & 6.93 & 7.66 \\
\hline ervices & 6.4 & 6.80 & 7.40 & 5.80 & 5.70 & 4.60 & 5.30 & 6.40 & 7.50 & 7.00 & 5.70 & 7.80 & 6.50 & 5.50 & 5.70 & 5.20 & 5.26 \\
\hline DP & 6.1 & 4.40 & 4.00 & 4.20 & 5.40 & 5.70 & 6.20 & 5.80 & 6.90 & 6.50 & 6.50 & 6.50 & 6.50 & 6.30 & 6.40 & 6.29 & 6.11 \\
\hline $\begin{array}{l}\text { GDP without Oil } \\
\& \text { Gas }\end{array}$ & 6.5 & 4.80 & 4.40 & 4.60 & 5.80 & 6.10 & 6.60 & 6.20 & 7.40 & 6.90 & 7.00 & 6.90 & 7.10 & 6.70 & 6.90 & 6.84 & 6.73 \\
\hline
\end{tabular}

Source: Retrieved from http://www.bps.go.id/. 
Table 2

Export Growth to Some Destination Countries

\begin{tabular}{lrrr}
\hline Destination & Jan-Oct 2011 & Jan-Oct 2012 & Growth \\
\hline ASEAN & $27,241.70$ & $25,777.40$ & $-5.68 \%$ \\
Singapore & $9,498.30$ & $8,487.60$ & $-11.91 \%$ \\
Malaysia & $7,593.60$ & $7,148.80$ & $-6.22 \%$ \\
Thailand & $4,560.30$ & $4,576.40$ & $0.35 \%$ \\
Other ASEAN & $5,589.50$ & $5,564.60$ & $-0.45 \%$ \\
EU & $17,137.40$ & $14,954.70$ & $-14.60 \%$ \\
Germany & $2,780.20$ & $2,590.60$ & $-7.32 \%$ \\
France & $1,109.60$ & 961.40 & $-15.42 \%$ \\
U.K. & $1,433.20$ & $1,443.70$ & $0.73 \%$ \\
China & $17,136.10$ & $16,821.80$ & $-1.87 \%$ \\
Japan & $15,168.00$ & $14,399.90$ & $-5.33 \%$ \\
U.S. & $13,222.80$ & $12,232.30$ & $-8.10 \%$ \\
South Korea & $6,389.10$ & $5,583.60$ & $-14.43 \%$ \\
\hline
\end{tabular}

Source: Statistics Indonesia (2012).

Meanwhile, the share of export to the U.S. was $10 \%$, lower than that of those countries. Therefore, the overall exports to those countries and regions amounted to $71 \%$ of total exports. Two other countries that are also the big buyers of Indonesian export goods are China and Japan, 13\% and 10\%, respectively. This means that these four countries-U.S., EU, China, and Japan-account for 45\% of Indonesian exports. Not all commodities are affected by a decline in exports. By performing a two digit analysis of the HS code, it was found that the phenomenon of decline in exports to some Asian countries, EU countries, and the U.S. only occurred in some commodities. In the meantime, however, exports of other commodities have continued to experience positive growth.

Table 3 shows that there are 15 export commodities which experienced negative growth for EU countries, U.S., ASEAN, Japan, China, and South Korea. Exports to the some Asian countries with the three biggest negative growths were coal and iron ore mining and other mining and quarrying and followed by manufacture of beverages while for the EU countries were coal and iron ore mining and crude oil, natural gas and geothermal mining and followed by manufacture of beverages. The biggest negative growth of export to the U.S. was coal and iron ore mining and crude oil, natural gas and geothermal mining and followed by manufacture of rubber and plastic wares.

Table 3

Export Growth to EU, U.S., and Asia (ASEAN, Japan, China, and South Korea) by Sector From Jan-Oct 2011 to Jan-Oct 2012

\begin{tabular}{lllll}
\hline & & FOB USD & FOB USD & Growth \\
\hline Sector No. Sector & Beans & 2011 & 2012 & $\%$ \\
2 & Vegetables and fruits & $2,484,300$ & $8,455,036$ & 240.34 \\
3 & Other food crops & $219,371,725$ & $160,697,995$ & -26.75 \\
4 & Tobacco & $135,747,575$ & $144,601,295$ & 6.52 \\
5 & Coffee & $433,753,899$ & $484,927,722$ & 11.80 \\
6 & Other estate crops & $331,285,772$ & $361,557,294$ & 9.14 \\
7 & & $610,838,753$ & $490,641,146$ & -19.68 \\
\hline
\end{tabular}


Table 3 continued

\begin{tabular}{|c|c|c|c|c|}
\hline & & FOB USD & FOB USD & Growth \\
\hline 8 & Other agriculture & $5,489,950,418$ & $5,826,260,442$ & 6.13 \\
\hline 9 & Livestock & $208,753,224$ & $184,902,829$ & -11.43 \\
\hline 10 & Slaughtering & 839,126 & 803,403 & -4.26 \\
\hline 11 & Poultry and its product & $6,173,700$ & $6,682,300$ & 8.24 \\
\hline 12 & Wood & $7,772,111$ & $12,109,391$ & 55.81 \\
\hline 13 & Other forest product & $11,030,190$ & $13,851,366$ & 25.58 \\
\hline 14 & Fishery & $829,914,517$ & $1,047,866,528$ & 26.26 \\
\hline 15 & Coal and metal ore mining & $4,797,272,474$ & $3,218,052,731$ & -32.92 \\
\hline 16 & Crude oil, natural gas and geothermal mining & $43,242,013,838$ & $41,836,002,555$ & -3.25 \\
\hline 17 & Other mining and quarrying & $6,155,911,548$ & $4,237,571,911$ & -31.16 \\
\hline 18 & Sugar factory & $53,429,000$ & $68,389,056$ & 28.00 \\
\hline 19 & Manufacture of other food products & $571,218,139$ & $702,447,372$ & 22.97 \\
\hline 20 & Manufacture of beverages & $95,509,692$ & $62,571,220$ & -34.49 \\
\hline 21 & Yarn spinning & $1,331,863,798$ & $1,188,593,845$ & -10.76 \\
\hline 22 & Manufacture of textile, wearing apparel and leather & $771,469,728$ & $1,052,245,971$ & 36.39 \\
\hline 23 & Manufacture of bamboo, wood and rattan products & $1,353,158,712$ & $1,429,363,127$ & 5.63 \\
\hline 24 & Manufacture of paper, paper products and cardboard & $2,315,488,792$ & $2,318,333,034$ & 0.12 \\
\hline 25 & Manufacture of fertilizer and pesticide & $141,092,548$ & $104,512,527$ & -25.93 \\
\hline 26 & Manufacture of chemicals & $5,121,859,771$ & $5,055,880,634$ & -1.29 \\
\hline 27 & Manufacture of rubber and plastic wares & $4,767,081,968$ & $3,684,667,460$ & -22.71 \\
\hline 28 & Manufacture of cement & $52,104,585$ & $44,194,568$ & -15.18 \\
\hline 29 & Manufacture of basic iron and steel & $1,263,434,837$ & $1,065,151,511$ & -15.69 \\
\hline 30 & Manufacture of fabricated metal products & $185,737,930$ & $146,583,929$ & -21.08 \\
\hline 31 & Manufacture of machine, electrical machinery and apparatus & $7,546,756,173$ & $7,621,089,323$ & 0.98 \\
\hline 32 & Manufacture of transport equipment and its repair & $2,480,684,351$ & $2,733,521,416$ & 10.19 \\
\hline 33 & Manufacture of other products not elsewhere classified & $2,666,650,818$ & $2,921,168,450$ & 9.54 \\
\hline Total & & $93,200,654,012$ & $88,233,697,387$ & -5.33 \\
\hline
\end{tabular}

Source: Statistics Indonesia (2012); authors' calculation.

\section{Impacts of Global Financial Crisis on Global Trade}

McKibbin and Stoeckel (2009) revealed that the global financial crisis could cause a severe economic contraction of global trade and production in 2009. The global financial crisis prompted many countries to issue some economic stimulus packages in order to survive. China, for example as described by W. Liu, Pannell, and H. Liu (2009), boosted its spending by half a trillion dollars to prop up economic growth through construction projects. This stimulus package becomes a sign that China began to focus on domestic consumption to design production growth and economic growth. This also indicates that China's policy of trade connections and the world economy affect each other.

Pula and Peltonen (2009) showed the connection and interdependence of the countries of Asia, U.S., EU, and Japan in the production and trade. This indicates that the crisis in some countries will affect the economies of others. Their research using Asia's input-output table also produced the absence of decoupling economies of Asia with the world economy. Contrary evidence is increasing trade integration, both regionally and globally. Although integration is increasing, the dependence of Asian countries to export is only a third of GDP far below 50\%.

Fukao and Yuan (2009) using the input-output table showed that the contraction of the Japanese economy is almost entirely due to the sharp decline in external demand. Fukao and Yuan (2009) also showed that Japan's 
contraction was the effect of triangular trade. In this context, the actual U.S. imports in 2007 and 2008 from Japan fell by $19 \%$ and 5\% of China. To understand how the impact of U.S. crisis on Japan's exports, one should include other factors such as global demand for investment goods, consumer goods, durable, and high-end products. Important aspect to note is that the multinational companies were the driving force behind the triangular trade. Half of China's exports to the U.S. tend to highly depend on imports of key components. It is possible that the contraction in the triangular trade has a major impact on Japan and Korea as both countries have multinational companies that invest and export drive in Asia, especially China. There is a problem to apply the input-output analysis, because the Asian input-output table does not distinguish between multinationals and local companies.

The crisis in the U.S. not only led to shrinking net exports of Japan to the U.S., but causing net exports of intermediate goods to Asian countries to be assembled and exported to the US declined as well. This decrease reached $11.8 \%$. As a result, Japan's GDP contracted twice the U.S. GDP (12.1\% vs. $6.3 \%)$. Unlike the Japanese who experienced significant decline due to the fall in external demand, the U.S. net exports declined by $0.15 \%$, meaning that $6.3 \%$ of GDP contraction is almost entirely due to lower domestic demand. It is important to note that the number of US households in 1990 to 2008 increased only slightly, while the number of installment debt quadrupled (Committee on Capital Markets Regulation, 2009).

Kuroiwa and Kuwamori (2010) examined the impact of global financial crisis of 2008 against the industry in East Asia by using Asian input-output table. The result showed that there was a significant impact on the crisis of eight East Asian countries, namely China, Japan, South Korea, Indonesia, Malaysia, Filipinos, Singapore, and Thailand. Kuroiwa and Kuwamori (2010) and Fukao and Yuan (2009) strengthened the view of the impact of global crisis on the triangular trade. Kuroiwa and Kuwamori found that the impact of the crisis was transmitted through the triangular trade. Significant portion affected by the crisis through the triangular trade is China. The pattern is as follows: China is a place of assembly, the neighboring countries in East Asia are suppliers, and the US and Europe are the end of the market. The impact of the crisis is export fall. This means that global financial crisis affected trade linkage besides other linkages.

Wang et al. (2011) measured how global financial crisis impacts China's GDP using input-output table. The result suggested that the global financial crisis hit China's economy in the fourth quarter of 2008 and third quarter of 2009 during which shrinkage of GDP amounted to CN 373.7 million and CN 649.1 million, respectively. Yuan, Liu, and Xie (2009) analyzed how the global financial crisis affects economic growth and energy consumption of China with the input-output analysis. This analysis showed that China's exports fall due to the crisis impact on GDP growth with a decrease to $-7.33 \%$ and $-9.21 \%$ in energy consumption.

For Indonesia, the study of Irawan, Anggraeni, and Oktaviani (2008) found that despite positive growth in Indonesia's manufacturing industry over the period 2003, there was a negative growth in the food industry, beverages, tobacco, textiles, leather and footwear (shoes and slippers), as well as cement (other papers for examples are Basri and Siregar (2009), Djaja (n.d.), Patunru and Zetha (2010), and Titiheruw et al. (2009)). By using input-output analysis, the results showed two important things. First, the impact of extreme economic conditions in the sub-sector of the industry is not profitable, but some sectors (agriculture-based industry) recovered faster than other sectors. Second, Indonesia's industrial structure remained unchanged and so did the Leontief coefficient that implies that there is no change in the technology of that period.

Wang et al. (2011) tried to calculate the impact of global financial crisis on economic growth and employment in China using input-output analysis. They analyzed the impact of the global financial crisis of 
2008 on the GDP and employment in China. Beginning with the impact on exports and investment, the input-output model is applied on the import of non-competitive type to approach the process of export goods. The results showed a more serious impact in the fourth quarter of 2008 and the third quarter of 2009. The fall in GDP in the fourth quarter of 2008 amounted to RMB 373.7 billion and in the third quarter of 2009 amounted to RMB 649.1 billion, equivalent to $8.3 \%$ of GDP in the third quarter of 2009. Throughout the same period, the number of unemployment increased from 12.51 million to 21.7 million.

\section{Use of Input-Output Analysis Method}

Input-output analysis has tendency of overestimated and has some weaknesses. The weaknesses inherent in the model input-output are a fixed coefficient and there is no supply constraint so that this condition does not consider economies of scale and input substitution (Miller \& Blair, 2009). This is demonstrated by the research Zhong, Hara, Ro, and Dickson (2011) who found that the negative impact on the accommodation and food services sector is highly overestimated by the difference amounting to two billion dollars. Similarly, the effects of lost employment are also overestimated.

Even though the method has some weakness, the less data requirement and adequate accuracy for short run potential impact are the advantage of this approach. Therefore, if adequate resources are available, non-linear analysis or Computable General Equilibrium (CGE) models can be used. However, given such resource constraint, input-output simulation can provide rough indication of the potential impact of global financial crisis to the Indonesian economy.

Input-output table is a picture of linkages among sectors, i.e. transactions among sectors, reflected by the flow/movement of goods among sectors or among the input transactions. The structure of input-output table is as follows:

$$
(I-A) X=Y
$$

That equation can be used to measure the impact of exogenous variable (the change of final demand $Y$ ) to the output $X$.

As $(I-A) X=Y$, then, $X=(I-A)^{-1} Y$, where $(I-A)^{-1}$ is the Leontief inverse matrix or $B$.

Then, the simulation is to give an impact of exports change (part of final demand) as follows:

$$
X=B Y x
$$

$Y x=$ exports change

Then to measure the value added impact, the follows can be got:

$V=\tilde{V} X$

$V=$ matrix of value added,

$\tilde{V}=$ diagonal matrix of value added,

$X=B Y x$.

To measure the employment impact, the follows can be got:

$L=\dot{L} B Y x$,

$L=$ required employment due to the change of final demand,

$\dot{L}=$ diagonal matrix of employment coefficient.

The data used are from the Statistics Indonesia (Badan Pusat Statistik) which is detailed by HS commodity. From these data, data export to these countries and regions during the period from January to October 2011 to January to October 2012 was calculated (Statistics Indonesia, 2012). Input-output table of 2005 is used because 
it is the latest data available (Statistics Indonesia, 2008). Input-output analysis can be made by simulating a decrease in export demand (final demand) of a sector and measured the effect or impact on the national economy through its influence on other sectors of the economy. The assumption of this study is that the decline in exports occurred in the destination countries and regions in certain sectors resulting in the decline in revenues due to debt and financial crisis in the EU and the U.S.. The magnitude of the impact to export growth for each country and region is different depending on the share and the fall of income in respecting country or region or the demand for the Indonesian export goods. Therefore, giving shock or pressure in lower exports to the countries and regions of destination is a simulation that is based on export performance during the period from January to October 2011 and January-October 2012.

The first simulation is the shock of total export growth (ASEAN, Japan, China, South Korea, EU, and the U.S.). The magnitude of shock is based on the export growth to those countries and region. The second simulation is the shock of export growth to Asia (ASEAN, Japan, China, South Korea). The third simulation is the shock of export growth to EU. The fourth simulation is the shock of export growth to the U.S.. The detail shock of those export fall is in Appendices .

\section{Potential Impact of the Value Added}

Under the conditions of the previous discussion, some simulations were made to measure the impact of the economic crisis that occurred in the EU and the U.S. on the value added (GDP) and employment. Based on the third simulation, this economic crisis in the EU affecting major trading partners (EU, U.S., and some Asian countries) caused negative economic growth by $1.06 \%$. The second simulation resulted in a negative growth by $0.61 \%$. Meanwhile, the third simulation in which the change of Indonesian exports to the EU countries experiencing the financial crisis caused its GDP to decline by $0.24 \%$. The drop of exports to the US has caused the decline of Indonesia's GDP by $0.2 \%$.

The global financial crisis led to shrank of the growth of Indonesia's GDP by $1.06 \%$ (Table 4). This is because of two things: First, the decline in exports occurs in some commodities; second, the market share of exports to these countries is relatively high, i.e. approximately $70 \%$ of total exports of Indonesia.

Table 4

Potential Impact of Export Change

\begin{tabular}{llll}
\hline No. & Countries/Regions & GDP $(\%)$ & Employment $(\%)$ \\
\hline 1 & Asia* & $-0.61 \%$ & -0.18 \\
2 & EU & $-0.24 \%$ & -0.22 \\
3 & U.S. & $-0.20 \%$ & -0.07 \\
4 & All & $-1.06 \%$ & -0.47 \\
\hline
\end{tabular}

Notes. *ASEAN, China, Japan, and South Korea. Source: Statistics Indonesia (2008); author's calculation.

Based on the simulation of decline in exports to major trading partners, there are 15 commodities which experienced a major decline in the value-added where five of which are crude oil, natural gas and geothermal mining, other mining and quarrying, coal and metal ore mining, manufacture of rubber and plastic wares, and manufacture of chemicals.

Interaction among sectors shows that although the decline was not in the 15 sectors mentioned above, but its impact also flowed into other sectors including the financial sector. This is presumably due to the condition when many sectors using the financial sector services went down the financial sector followed. The same is 
applied for the railway transport sector. Coal sector is using rail transport. When the coal sector has decreased in value-added, of course railway sector decreased as well.

The above illustration shows that the input-output analysis can provide detail linkages among sectors: Demand reduction at one sector will give an impact on other sectors. If the linkage is high, the change in demand for the sector will have broad impact. This is one of the advantages of input-output analysis. Overall, the decline in value added was IDR 88.79 trillion or caused a decline in GDP growth of $-1.06 \%$. It is actually less than that of the decline of GDP growth of 2008. The recent global crisis seemed to less affect Indonesian economy.

Table 5 shows that shock in exports in the five sectors due to the fall of exports has led to lower demand in other sectors and this can be seen in the column of industrial support and of falling consumption due to falling income. There were 15 sectors experiencing a large decrease in value added where the largest decrease was experienced by crude oil, natural gas and geothermal mining among other things. Other sectors out of five sectors mentioned above experienced larger decrease while they had not been given shock decrease. It means that the decline sectors have substantial linkages with other sectors and have synergistic effect with other sectors, causing a shock to other sectors such as trade sector which emerged as the largest decline after coal and metal ore mining.

Table 5

Value Added of Final Demand Impacts of Total (Asia, EU, and U.S.), in IDR Million

\begin{tabular}{llllll}
\hline No. & Sector & Final demand & Industrial support & Consumption & Total \\
\hline 1 & Crude oil, natural gas and geothermal mining & $-20,404,931$ & $-4,110,280$ & $-242,063$ & $-24,757,274$ \\
2 & Other mining and quarrying & $-14,937,030$ & $-117,237$ & $-14,850$ & $-15,069,118$ \\
3 & Coal and metal ore mining & $-12,284,612$ & $-1,417,755$ & $-53,177$ & $-13,755,544$ \\
4 & Manufacture of rubber and plastic wares & $-11,756,279$ & $-794,020$ & $-230,024$ & $-12,780,324$ \\
5 & Manufacture of chemicals & $-2,742,491$ & $-2,209,204$ & $-244,513$ & $-5,196,208$ \\
6 & Trade & 0 & $-1,663,922$ & $-2,248,709$ & $-3,912,631$ \\
7 & Rubber & 0 & $-3,000,259$ & $-59,351$ & $-3,059,611$ \\
8 & Petroleum refinery & 0 & $-1,921,703$ & $-455,895$ & $-2,377,597$ \\
9 & Manufacture of textile, wearing apparel and leather & $-1,330,874$ & $-353,128$ & $-275,075$ & $-1,959,078$ \\
10 & Yarn spinning & $-1,231,296$ & $-598,530$ & $-58,516$ & $-1,888,342$ \\
11 & Other services & 0 & $-762,251$ & $-643,069$ & $-1,405,320$ \\
12 & Other estate crops & $-1,129,620$ & $-87,032$ & $-23,713$ & $-1,240,365$ \\
13 & Financial intermediaries & 0 & $-552,468$ & $-686,929$ & $-1,239,397$ \\
14 & Manufacture of basic iron and steel & $-1,073,670$ & $-56,560$ & $-18,624$ & $-1,148,854$ \\
15 & Vegetables and fruits & $-477,020$ & $-71,966$ & $-541,860$ & $-1,090,847$ \\
\hline
\end{tabular}

Source: Statistics Indonesia (2008); authors' calculation.

\section{Potential Impact on Employment}

Due to the crisis which led to the decrease inf exports to some Asian countries, EU countries and the U.S. as well as in total, it will have an impact on employment in Indonesia. The sectors that experienced a decrease of employment can be seen in Table 6. Fifteen of the sectors which had the highest job reduction were other mining and quarrying, vegetables and fruits, trade, rubber, manufacture of rubber and plastic wares, manufacture of textile, wearing apparel and leather etc.. Some of these sectors employment decline was due to the fall of final demand. However, other sectors employment decline was due to strong linkage to other sectors most 
affected by the global crisis, such as trade and rubber. However, the significant impact on employment came from the reduction of exports to some Asian countries. The detail employment reductions are shown in Table 6.

Table 6

The Potential Impact on Employment

\begin{tabular}{|c|c|c|c|c|c|}
\hline No. & Sector & Final demand & $\begin{array}{l}\text { Industrial } \\
\text { support }\end{array}$ & Consumption & Total \\
\hline 1 & Other mining and quarrying & $-281,419$ & $-2,209$ & -280 & $-283,907$ \\
\hline 2 & Vegetables and fruits & $-72,320$ & $-10,911$ & $-82,150$ & $-165,380$ \\
\hline 3 & Trade & 0 & $-61,647$ & $-83,313$ & $-144,960$ \\
\hline 4 & Rubber & 0 & $-122,566$ & $-2,425$ & $-124,990$ \\
\hline 5 & Manufacture of rubber and plastic wares & $-78,467$ & $-5,300$ & $-1,535$ & $-85,302$ \\
\hline 6 & Manufacture of textile, wearing apparel and leather & $-38,080$ & $-10,104$ & $-7,871$ & $-56,054$ \\
\hline 7 & Other services & 0 & $-26,287$ & $-22,177$ & $-48,464$ \\
\hline 8 & Other estate crops & $-31,640$ & $-2,438$ & -664 & $-34,742$ \\
\hline 9 & Yarn spinning & $-17,536$ & $-8,524$ & -833 & $-26,893$ \\
\hline 10 & Root crops & 0 & 1,941 & $-27,730$ & $-25,789$ \\
\hline 11 & Coal and metal ore mining & $-22,482$ & $-2,595$ & -97 & $-25,174$ \\
\hline 12 & Road transport & 0 & $-14,693$ & $-9,121$ & $-23,814$ \\
\hline 13 & Social and community, services & 0 & $-2,205$ & $-15,642$ & $-17,847$ \\
\hline 14 & Crude oil, natural gas and geothermal mining & $-12,579$ & $-2,534$ & -149 & $-15,263$ \\
\hline 15 & Livestock & $-9,680$ & 1,892 & $-7,187$ & $-14,976$ \\
\hline
\end{tabular}

Source: Statistics Indonesia (2008); authors' calculation.

\section{Capital Expenditure of State Budget of 2013}

The government of Indonesia tried to ease the potential impact of global financial crisis by increasing capital expenditure of state budget of 2013. The amount of capital expenditure is IDR 184.4 trillion. Using coefficient of capital expenditure, authors applied a simulation to measure the impact of such policy to offset export decline.

The results of simulation showed that the impact is so small compared to the impact of export decline. In other words, there is no significant impact. It might be that the targeted sectors of capital expenditure are not the key sectors that provide high contribution to economic growth and employment creation. Therefore, the impact of public capital spending is very small. The value added decline by IDR 88,786,321,000,000 compared to IDR $88,785,327,000,000$ without capital expenditure.

\section{Conclusions}

The U.S. sub-prime mortgage crisis in 2008 has a strong impact on Indonesia where Indonesia's GDP growth has virtually halted below 5\% during 2009. Based on the export data of Statistics Indonesia from January to October 2012, the crises in the EU and the U.S. have caused Indonesia's export to experience negative growth on some sectors. Although this slow-down does not occur in all sectors, the impact is quite spread-out due to the linkages amongst sectors.

The simulation results show that if exports decline occurs in the U.S., the economic growth will decline by $0.20 \%$ from the base case. Meanwhile, if it occurs in the EU, the growth of GDP will decline by $0.24 \%$ from the base case. If some Asian countries face the fall of demand of Indonesian export, GDP growth will decline 
by $0.61 \%$ from the base case. The fall of exports demand from some Asian countries, EU countries, and the U.S. will cause the GDP growth by $-1.06 \%$ from the base case. The crisis occurring in both the U.S. and the EU has decreased export demand from those countries and region including some Asian countries. The impact to employment seemed to be minimal, only $-0.47 \%$ of total labour force.

Policy implications in anticipation of the potential impact of the crisis are through fiscal stimulus as government had ever done in 2008. However, fiscal stimulus based on budget 2013 such as capital expenditure might not be effective to soften the impact of global financial crisis, if capital expenditure is not targeted to the sectors that provide high GDP growth and employment creation. The fiscal stimulus policy will not be effective unless capital expenditure is applied on sectors that suffered the most from the serious impacts in terms of value added and job creation.

Other policies can be stimulus and fiscal incentives for the sectors that experienced a decline in export demand for the U.S. and the EU. Creation of new markets and non-traditional markets such as Africa and the Middle East would be necessary to offset the decline of traditional markets. If the new markets of export destinations increase, the impact of the crisis will not be too significant for the domestic economy.

\section{References}

Adriyanto. (2010). Coping with the global financial crisis: Indonesia's experience during 2008-2009. Retrieved from http://www.fiskal.depkeu.go.id/2010/ adoku/ Adriyanto1.1.pdf

Basri, M. C., \& Siregar, R. Y. (2009). Navigating policy responses at the national level in the midst of the global financial crisis: The experience of Indonesia. Asian Economic Papers, 8(3), 1-35.

Berkmen, P., Gelos, G., Rennhack, R., \& Walsh, J. P. (2009). The global financial crisis: Explaining cross-country differences in the output impact (IMF Working Paper WP/09/280). Retrieved from http://www.imf. org/external/pubs/ft/wp/2009/wp09280.pdf

Committee on Capital Markets Regulation. (2009). The global financial crisis: A plan for regulatory reform. Retrieved from www.capmktsreg.org/pdfs/TGFC-CCMR_Report_(5-26-09).pdf

Djaja, K. (n.d.). Impact of the global financial and economic crisis on Indonesia: A rapid assessment. Retrieved from http://natlex.ilo.ch/wcmsp5/groups/public/---asia/---ro-bangkok/documents/meetingdocument/wcms_101594.pdf

Fukao, K., \& Yuan, T. (2009). Why is Japan so heavily affected by the global economic crisis? An analysis based on the Asian international input-output tables. Retrieved from http://www.voxeu.org/article/why-has-japan-been-so-hard-hit-global-crisis

Griffith-Jones, S., \& Ocampo, J. A. (2009). The financial crisis and its impact on developing countries. Retrieved from http://www.undp.org/content/dam/aplaws/publication/en/publications/poverty-reduction/poverty-website/the-financial-crisisand-its-impact-on-developing-countries/PG-2009-001-discussion-paper-financial-crisis-Griffith-Jones_Ocampo.pdf

Guimarães-Filho, R., Hori, M., Miniane, J., \& N'Diaye, P. (2008). Can Asia decouple? Investigating spillovers from the United States to Asia (International Monetary Fund, Regional Economic Outlook Asia and Pacific (April)). Retrieved from http://www.imf.org/external/ft/reo/2008/APD/ ENG/areo0408.pdf

Irawan, T., Anggraeni, L., \& Oktaviani, R. (2008). The role of manufacturing industry to Indonesia economic performance: Input-output analysis. Retrieved from http://ekonomi.fem.ipb.ac.id/doc/10.pdf

Kuroiwa, I., \& Kuwamori, H. (2010). Shock transmission mechanism of the economics crisis in East Asia: An application of international input-output analysis (Institute of Developing Economies Discussion Paper No. 220). Retrieved from http://ir.ide.go.jp/dspace/bitstream/2344/869/1/220.pdf

Liu, W., Pannell, C. W., \& Liu, H. (2009). The global economics crisis and China's foreign trade. Retrieved from http://relooney.fatcow.com/SI_FAO-Asia/China_245.pdf

McKibbin, J. W., \& Stoeckel, A. (2009). The potential impact of the global financial crisis on world trade. Retrieved from http://www-wds.worldbank.org/external/default/WDSContentServer/IW3P/IB/2009/11/18/000158349_20091118083139/Re ndered/PDF/WPS5134.pdf

Miller, R. E., \& Blair, P. D. (2009). Input-output analysis: Foundations and extensions (2nd ed.). Rietrieved from http://digamo. free.fr/io2009.pdf 
Patunru, A., \& Zetha, E. (2010). Indonesia's savior: Fiscal, monetary, trade, or luck? Retrieved from http://www.mof.go. jp/english/pri/publication/pp_review/ppr010/ppr010g.pdf

Pula, G., \& Peltonen, T. A. (2009). Has emerging Asia decoupled? An analysis of production and trade linkages using the Asian international input-output table (Working Paper Series No. 993, European Central Bank). Retrieved from http://www.ecb.europa.eu/pub/pdf/scpwps/ecbwp993.pdf\&ei

Statistics Indonesia. (2002-2013). Berita Resmi Statistik (Pertumbuhan Ekonomi Indonesia, Jakarta). Retrieved from http://www.bps.go.id/

Statistics Indonesia. (2008). The Input Output Table of 2005. Jakarta: Badan Pusat Statistik.

Statistics Indonesia. (2012). Data Ekspor Berdasarkan Komoditi (HS) dan Negara Tujuan ASEAN Plus Three, AS dan Uni Eropa (soft copy).

Titiheruw, I. S., Soesastro, H., \& Atje, R. (2009). Global financial crisis (In Discussion Series Paper 6: Indonesia, Overseas Development Institute 111 Westminster Bridge Road London SE1 7JD). Retrieved from http://www.odi.org.uk/sites/odi.org.uk/files/odi-assets/publications-opinion-files/4327.pdf

Wang, H., Chen, X., \& Yang, C. (2011). How much does the international financial crisis affect China's GDP and employment? Retrieved from https://www.iioa.org/conferences/18th/papers/files/42_20100227060_HowmuchdoestheinternationalfinancialcrisisaffectChia n'sGDPandEmeploment-HuijuanWANG.pdf

Wie, T. K. (2012). The Indonesian economy after the global financial crisis. Retrieved from http://www.crawford.anu.edu. au/acde/ip/pdf/lpem/2012/2012_10_24_-_SEADI_Thee_Kian_Wie.pdf

Yuan, C, Liu, C., \& Xie, N. (2010). The impact on Chinese economic growth and energy consumption of the global financial crisis: An input-output analysis. Energy, 35(4), 1805-1812.

Zhong, Y. Y., Hara, T., Ro, H., \& Dickson, D. (2011). Quantifying the impacts of the recent economic crisis on a local tourism industry and economy system. Retrieved from http://scholarworks.umass.edu/cgi/viewcontent.cgi? article $=1048 \&$ context=gradconf_hospitality

Appendices

Appendix 1. Number and Sector Classification Input-Output Table of 2005

\begin{tabular}{ll}
\hline No. Sector & Sector \\
\hline 1 & Paddy \\
2 & Beans \\
3 & Maize \\
4 & Root crops \\
5 & Vegetables and fruits \\
6 & Other food crops \\
7 & Rubber \\
8 & Sugarcane \\
9 & Coconut \\
10 & Oil palm \\
11 & Tobacco \\
12 & Coffee \\
13 & Tea \\
14 & Clove \\
15 & Fibber crops \\
16 & Other estate crops \\
17 & Other agriculture \\
18 & Livestock \\
19 & Slaughtering \\
20 & Poultry and its product \\
21 & Wood \\
\hline
\end{tabular}


Appendix 1 continued

\begin{tabular}{|c|c|}
\hline No. Sector & Sector \\
\hline 22 & Other forest product \\
\hline 23 & Fishery \\
\hline 24 & Coal and metal ore mining \\
\hline 25 & Crude oil, natural gas, and geothermal mining \\
\hline 26 & Other mining and quarrying \\
\hline 27 & Manufacture of food processing and preserving \\
\hline 28 & Manufacture of oil and fat \\
\hline 29 & Rice milling \\
\hline 30 & Manufacture of flour, all kinds \\
\hline 31 & Sugar factory \\
\hline 32 & Manufacture of other food products \\
\hline 33 & Manufacture of beverages \\
\hline 34 & Manufacture of cigarettes \\
\hline 35 & Yarn spinning \\
\hline 36 & Manufacture of textile, wearing apparel, and leather \\
\hline 37 & Manufacture of bamboo, wood, and rattan products \\
\hline 38 & Manufacture of paper, paper products, and cardboard \\
\hline 39 & Manufacture of fertilizer and pesticide \\
\hline 40 & Manufacture of chemicals \\
\hline 41 & Petroleum refinery \\
\hline 42 & Manufacture of rubber and plastic wares \\
\hline 43 & Manufacture of non metallic mineral products \\
\hline 44 & Manufacture of cement \\
\hline 45 & Manufacture of basic iron and steel \\
\hline 46 & Manufacture of nonferrous basic metal \\
\hline 47 & Manufacture of fabricated metal products \\
\hline 48 & Manufacture of machine, electrical machinery, and apparatus \\
\hline 49 & Manufacture of transport equipment and its repair \\
\hline 50 & Manufacture of other products not elsewhere classified \\
\hline 51 & Electricity, gas, and water supply \\
\hline 52 & Construction \\
\hline 53 & Trade \\
\hline 54 & Restaurant and hotel \\
\hline 55 & Railway transport \\
\hline 56 & Road transport \\
\hline 57 & Water transport \\
\hline 58 & Air transport \\
\hline 59 & Services allied to transport \\
\hline 60 & Communication \\
\hline 61 & Financial intermediaries \\
\hline 62 & Real estate and business service \\
\hline 63 & General government and defense \\
\hline 64 & Social community, services \\
\hline 65 & Other services \\
\hline 66 & Unspecified sector \\
\hline
\end{tabular}

Source: Statistics Indonesia (2008). 
Appendix 2. The Magnitude of Shock in Input-Output Table of 2005

\begin{tabular}{|c|c|c|c|c|c|}
\hline & & Asia* & EU & US & $\begin{array}{l}\text { Total } \\
\text { (Asia, EU and } \\
\text { US) }\end{array}$ \\
\hline $\begin{array}{l}\text { Input-Output } \\
\text { Code }\end{array}$ & Sector & US\$ & US\$ & US\$ & US\$ \\
\hline 2 & Beans & $5,970,736$ & 71,011 & 145,349 & $6,187,096$ \\
\hline 5 & Vegetables and fruits & $-58,673,730$ & $-4,267,978$ & $4,413,597$ & $-58,528,111$ \\
\hline 6 & Other food crops & $8,853,720$ & $-3,501,024$ & 15,338 & $5,368,034$ \\
\hline 11 & Tobacco & $51,173,823$ & $4,525,434$ & $3,190,676$ & $58,889,933$ \\
\hline 12 & Coffee & $30,271,522$ & $53,025,381$ & $118,497,054$ & $201,793,957$ \\
\hline 16 & Other estate crops & $-120,197,607$ & $4,302,729$ & $-47,466,426$ & $-163,361,304$ \\
\hline 17 & Other agriculture & $336,310,024$ & $103,830,070$ & $-74,099,412$ & $366,040,682$ \\
\hline 18 & Livestock & $-23,850,395$ & 784,404 & $1,309,957$ & $-21,756,034$ \\
\hline 19 & Slaughtering & $-35,723$ & $-829,608$ & 51,345 & $-813,986$ \\
\hline 20 & Poultry and its product & 508,600 & $2,066,563$ & 612,765 & $3,187,928$ \\
\hline 21 & Wood & $4,337,280$ & $12,378,759$ & $2,370,975$ & $19,087,014$ \\
\hline 22 & Other forest product & $2,821,176$ & $1,332,503$ & $-1,290,741$ & $2,862,938$ \\
\hline 23 & Fishery & $217,952,011$ & $-7,356,219$ & $98,730,911$ & $309,326,703$ \\
\hline 24 & Coal and metal ore mining & $-1,579,219,743$ & $-70,611,091$ & $-81,072,891$ & $-1,730,903,725$ \\
\hline 25 & Crude oil, natural gas and geothermal mining & $-1,406,011,283$ & $-464,663,775$ & $-548,721,367$ & $-2,419,396,425$ \\
\hline 26 & Other mining and quarrying & $-1,918,339,637$ & $-41,963,627$ & $-48,370,174$ & $-2,008,673,438$ \\
\hline 31 & Sugar factory & $14,960,056$ & $-4,188,135$ & $5,121,737$ & $15,893,658$ \\
\hline 32 & Manufacture of other food products & $131,229,233$ & $-4,454,368$ & $-13,822,135$ & $112,952,730$ \\
\hline 33 & Manufacture of beverages & $-32,938,472$ & $-1,309,219$ & $6,624,814$ & $-27,622,877$ \\
\hline 35 & Yarn spinning & $-143,269,953$ & $-83,669,291$ & $7,848,383$ & $-219,090,861$ \\
\hline 36 & $\begin{array}{l}\text { Manufacture of textile, wearing apparel and } \\
\text { leather }\end{array}$ & $280,776,243$ & $-153,920,964$ & $-440,337,205$ & $-313,481,926$ \\
\hline 37 & $\begin{array}{l}\text { Manufacture of bamboo, wood and rattan } \\
\text { products }\end{array}$ & $76,204,415$ & $-52,678,444$ & $23,759,109$ & $47,285,080$ \\
\hline 38 & $\begin{array}{l}\text { Manufacture of paper, paper products and } \\
\text { cardboard }\end{array}$ & $2,844,242$ & $-20,591,103$ & $12,240,139$ & $-5,506,722$ \\
\hline 39 & Manufacture of fertilizer and pesticide & $-36,580,021$ & $-76,608$ & $101,932,527$ & $65,275,898$ \\
\hline 40 & Manufacture of chemicals & $-65,979,137$ & $-385,199,018$ & $-51,468,516$ & $-502,646,671$ \\
\hline 42 & Manufacture of rubber and plastic wares & $-1,082,414,508$ & $-618,846,342$ & $-917,218,116$ & $-2,618,478,966$ \\
\hline 44 & Manufacture of cement & $-7,910,017$ & 418,055 & $1,518,799$ & $-5,973,163$ \\
\hline 45 & Manufacture of basic iron and steel & $-198,283,326$ & $-43,001,195$ & $22,024,578$ & $-219,259,943$ \\
\hline 47 & Manufacture of fabricated metal products & $-39,154,001$ & $-2,858,002$ & $4,910,775$ & $-37,101,228$ \\
\hline 48 & $\begin{array}{l}\text { Manufacture of machine, electrical machinery, } \\
\text { and apparatus }\end{array}$ & $74,333,150$ & $108,858,638$ & $83,895,656$ & $267,087,444$ \\
\hline 49 & $\begin{array}{l}\text { Manufacture of transport equipment and its } \\
\text { repair }\end{array}$ & $252,837,065$ & $18,036,491$ & $6,394,201$ & $277,267,757$ \\
\hline 50 & $\begin{array}{l}\text { Manufacture of other products not elsewhere } \\
\text { classified }\end{array}$ & $254,517,632$ & $-73,027,862$ & $215,521,656$ & $397,011,426$ \\
\hline TOTAL & & $-4,966,956,625$ & $-1,727,383,835$ & $-1,502,736,642$ & $-8,197,077,102$ \\
\hline
\end{tabular}

Note. *ASEAN, China, Japan, and South Korea. Source: Statistics Indonesia and authors' calculation. 
Appendix 3. Export Growth to Some Asian* Countries by Input-Output Code (Jan-Oct 2011-2012)

\begin{tabular}{|c|c|c|c|c|c|c|}
\hline & & & Asia & & Change & \\
\hline No. & $\begin{array}{l}\text { Input-Output } \\
\text { Code }\end{array}$ & Sector & 2011 & 2012 & US\$ & $\%$ \\
\hline 1 & 2 & Beans & $2,484,300$ & $8,455,036$ & $5,970,736$ & 240.34 \\
\hline 2 & 5 & Vegetables and fruits & $219,371,725$ & $160,697,995$ & $-58,673,730$ & -26.75 \\
\hline 3 & 6 & Other food crops & $135,747,575$ & $144,601,295$ & $8,853,720$ & 6.52 \\
\hline 4 & 11 & Tobacco & $433,753,899$ & $484,927,722$ & $51,173,823$ & 11.80 \\
\hline 5 & 12 & Coffee & $331,285,772$ & $361,557,294$ & $30,271,522$ & 9.14 \\
\hline 6 & 16 & Other estate crops & $610,838,753$ & $490,641,146$ & $-120,197,607$ & -19.68 \\
\hline 7 & 17 & Other agriculture & $5,489,950,418$ & $5,826,260,442$ & $336,310,024$ & 6.13 \\
\hline 8 & 18 & Livestock & $208,753,224$ & $184,902,829$ & $-23,850,395$ & -11.43 \\
\hline 9 & 19 & Slaughtering & 839,126 & 803,403 & $-35,723$ & -4.26 \\
\hline 10 & 20 & Poultry and its product & $6,173,700$ & $6,682,300$ & 508,600 & 8.24 \\
\hline 11 & 21 & Wood & $7,772,111$ & $12,109,391$ & $4,337,280$ & 55.81 \\
\hline 12 & 22 & Other forest product & $11,030,190$ & $13,851,366$ & $2,821,176$ & 25.58 \\
\hline 13 & 23 & Fishery & $829,914,517$ & $1,047,866,528$ & $217,952,011$ & 26.26 \\
\hline 14 & 24 & Coal and metal ore mining & $4,797,272,474$ & $3,218,052,731$ & $-1,579,219,743$ & -32.92 \\
\hline 15 & 25 & $\begin{array}{l}\text { Crude oil, natural gas and geothermal } \\
\text { mining }\end{array}$ & $43,242,013,838$ & $41,836,002,555$ & $-1,406,011,283$ & -3.25 \\
\hline 16 & 26 & Other mining and quarrying & $6,155,911,548$ & $4,237,571,911$ & $-1,918,339,637$ & -31.16 \\
\hline 17 & 31 & Sugar factory & $53,429,000$ & $68,389,056$ & $14,960,056$ & 28.00 \\
\hline 18 & 32 & Manufacture of other food products & $571,218,139$ & $702,447,372$ & $131,229,233$ & 22.97 \\
\hline 19 & 33 & Manufacture of beverages & $95,509,692$ & $62,571,220$ & $-32,938,472$ & -34.49 \\
\hline 20 & 35 & Yarn spinning & $1,331,863,798$ & $1,188,593,845$ & $-143,269,953$ & -10.76 \\
\hline 21 & 36 & $\begin{array}{l}\text { Manufacture of textile, wearing apparel, } \\
\text { and leather }\end{array}$ & $771,469,728$ & $1,052,245,971$ & $280,776,243$ & 36.39 \\
\hline 22 & 37 & $\begin{array}{l}\text { Manufacture of bamboo, wood, and } \\
\text { rattan products }\end{array}$ & $1,353,158,712$ & $1,429,363,127$ & $76,204,415$ & 5.63 \\
\hline 23 & 38 & $\begin{array}{l}\text { Manufacture of paper, paper products, } \\
\text { and cardboard }\end{array}$ & $2,315,488,792$ & $2,318,333,034$ & $2,844,242$ & 0.12 \\
\hline 24 & 39 & Manufacture of fertilizer and pesticide & $141,092,548$ & $104,512,527$ & $-36,580,021$ & -25.93 \\
\hline 25 & 40 & Manufacture of chemicals & $5,121,859,771$ & $5,055,880,634$ & $-65,979,137$ & -1.29 \\
\hline 26 & 42 & Manufacture of rubber and plastic wares & $4,767,081,968$ & $3,684,667,460$ & $-1,082,414,508$ & -22.71 \\
\hline 27 & 44 & Manufacture of cement & $52,104,585$ & $44,194,568$ & $-7,910,017$ & -15.18 \\
\hline 28 & 45 & Manufacture of basic iron and steel & $1,263,434,837$ & $1,065,151,511$ & $-198,283,326$ & -15.69 \\
\hline 29 & 47 & $\begin{array}{l}\text { Manufacture of fabricated metal } \\
\text { products }\end{array}$ & $185,737,930$ & $146,583,929$ & $-39,154,001$ & -21.08 \\
\hline 30 & 48 & $\begin{array}{l}\text { Manufacture of machine, electrical } \\
\text { machinery, and apparatus }\end{array}$ & $7,546,756,173$ & $7,621,089,323$ & $74,333,150$ & 0.98 \\
\hline 31 & 49 & $\begin{array}{l}\text { Manufacture of transport equipment and } \\
\text { its repair }\end{array}$ & $2,480,684,351$ & $2,733,521,416$ & $252,837,065$ & 10.19 \\
\hline 32 & 50 & $\begin{array}{l}\text { Manufacture of other products not } \\
\text { elsewhere classified }\end{array}$ & $2,666,650,818$ & $2,921,168,450$ & $254,517,632$ & 9.54 \\
\hline TOTAL & & & $93,200,654,012$ & $88,233,697,387$ & $-4,966,956,625$ & -5.33 \\
\hline
\end{tabular}

Note. *ASEAN, China, Japan, and South Korea. Source: Statistics Indonesia and authors' calculation. 
Appendix 4. Export Growth to European Union Countries by Input-Output Code Jan-Oct 2011-2012

\begin{tabular}{|c|c|c|c|c|c|c|}
\hline \multirow{2}{*}{ No. } & \multirow[b]{2}{*}{$\begin{array}{l}\text { Input-Output } \\
\text { Code }\end{array}$} & \multirow[b]{2}{*}{ Sector } & \multicolumn{2}{|c|}{ European Union Countries } & \multicolumn{2}{|l|}{ Change } \\
\hline & & & 2011 & 2012 & US\$ & $\%$ \\
\hline 1 & 2 & Beans & 12,258 & 83,269 & 71,011 & 579.30 \\
\hline 2 & 5 & Vegetables and fruits & $29,599,406$ & $25,331,428$ & $-4,267,978$ & -14.42 \\
\hline 3 & 6 & Other food crops & $33,828,208$ & $30,327,184$ & $-3,501,024$ & -10.35 \\
\hline 4 & 11 & Tobacco & $20,944,436$ & $25,469,870$ & $4,525,434$ & 21.61 \\
\hline 5 & 12 & Coffee & $236,608,675$ & $289,634,056$ & $53,025,381$ & 22.41 \\
\hline 6 & 16 & Other estate crops & $85,474,012$ & $89,776,741$ & $4,302,729$ & 5.03 \\
\hline 7 & 17 & Other agriculture & $2,061,208,861$ & $2,165,038,931$ & $103,830,070$ & 5.04 \\
\hline 8 & 18 & Livestock & $14,408,095$ & $15,192,499$ & 784,404 & 5.44 \\
\hline 9 & 19 & Slaughtering & $4,655,131$ & $3,825,523$ & $-829,608$ & -17.82 \\
\hline 10 & 20 & Poultry and its product & 405,339 & $2,471,902$ & $2,066,563$ & 509.84 \\
\hline 11 & 21 & Wood & $14,499,496$ & $26,878,255$ & $12,378,759$ & 85.37 \\
\hline 12 & 22 & Other forest product & $11,910,009$ & $13,242,512$ & $1,332,503$ & 11.19 \\
\hline 13 & 23 & Fishery & $95,574,755$ & $88,218,536$ & $-7,356,219$ & -7.70 \\
\hline 14 & 24 & Coal and metal ore mining & $131,347,891$ & $60,736,800$ & $-70,611,091$ & -53.76 \\
\hline 15 & 25 & $\begin{array}{l}\text { Crude oil, natural gas, and geothermal } \\
\text { mining }\end{array}$ & $879,486,428$ & $414,822,653$ & $-464,663,775$ & -52.83 \\
\hline 16 & 26 & Other mining and quarrying & $185,067,788$ & $143,104,161$ & $-41,963,627$ & -22.67 \\
\hline 17 & 31 & Sugar factory & $6,961,977$ & $2,773,842$ & $-4,188,135$ & -60.16 \\
\hline 18 & 32 & Manufacture of other food products & $71,728,586$ & $67,274,218$ & $-4,454,368$ & -6.21 \\
\hline 19 & 33 & Manufacture of beverages & $2,775,880$ & $1,466,661$ & $-1,309,219$ & -47.16 \\
\hline 20 & 35 & Yarn spinning & $311,683,636$ & $228,014,345$ & $-83,669,291$ & -26.84 \\
\hline 21 & 36 & $\begin{array}{l}\text { Manufacture of textile, wearing apparel, } \\
\text { and leather }\end{array}$ & $1,022,091,112$ & $868,170,148$ & $-153,920,964$ & -15.06 \\
\hline 22 & 37 & $\begin{array}{l}\text { Manufacture of bamboo, wood, and } \\
\text { rattan products }\end{array}$ & $328,121,134$ & $275,442,690$ & $-52,678,444$ & -16.05 \\
\hline 23 & 38 & $\begin{array}{l}\text { Manufacture of paper, paper products } \\
\text { and cardboard }\end{array}$ & $111,399,972$ & $90,808,869$ & $-20,591,103$ & -18.48 \\
\hline 24 & 39 & Manufacture of fertilizer and pesticide & 189,756 & 113,148 & $-76,608$ & -40.37 \\
\hline 25 & 40 & Manufacture of chemicals & $1,833,104,679$ & $1,447,905,661$ & $-385,199,018$ & -21.01 \\
\hline 26 & 42 & $\begin{array}{l}\text { Manufacture of rubber and plastic } \\
\text { wares }\end{array}$ & $1,451,183,542$ & $832,337,200$ & $-618,846,342$ & -42.64 \\
\hline 27 & 44 & Manufacture of cement & $18,346,062$ & $18,764,117$ & 418,055 & 2.28 \\
\hline 28 & 45 & Manufacture of basic iron and steel & $300,128,738$ & $257,127,543$ & $-43,001,195$ & -14.33 \\
\hline 29 & 47 & $\begin{array}{l}\text { Manufacture of fabricated metal } \\
\text { products }\end{array}$ & $16,343,809$ & $13,485,807$ & $-2,858,002$ & -17.49 \\
\hline 30 & 48 & $\begin{array}{l}\text { Manufacture of machine, electrical } \\
\text { machinery, and apparatus }\end{array}$ & $1,330,903,040$ & $1,439,761,678$ & $108,858,638$ & 8.18 \\
\hline 31 & 49 & $\begin{array}{l}\text { Manufacture of transport equipment and } \\
\text { its repair }\end{array}$ & $115,020,673$ & $133,057,164$ & $18,036,491$ & 15.68 \\
\hline 32 & 50 & $\begin{array}{l}\text { Manufacture of other products not } \\
\text { elsewhere classified }\end{array}$ & $1,354,339,412$ & $1,281,311,550$ & $-73,027,862$ & -5.39 \\
\hline TOT & & & $12,079,352,796$ & $10,351,968,961$ & $-1,727,383,835$ & -14.30 \\
\hline
\end{tabular}

Source: Statistics Indonesia and authors' calculation. 
Appendix 5. Export Growth to the United States by Input-Output Code (Jan-Oct 2011-2012)

\begin{tabular}{|c|c|c|c|c|c|c|}
\hline \multirow{2}{*}{ No. } & \multirow[b]{2}{*}{$\begin{array}{l}\text { Input-Output } \\
\text { Code }\end{array}$} & \multirow[b]{2}{*}{ Sector } & \multicolumn{2}{|l|}{ US } & \multicolumn{2}{|l|}{ Change } \\
\hline & & & 2011 & 2012 & US\$ & $\%$ \\
\hline 1 & 2 & Beans & 24,164 & 169,513 & 145,349 & 601.51 \\
\hline 2 & 5 & Vegetables and fruits & $7,928,180$ & $12,341,777$ & $4,413,597$ & 55.67 \\
\hline 3 & 6 & Other food crops & $7,157,794$ & $7,173,132$ & 15,338 & 0.21 \\
\hline 4 & 11 & Tobacco & $16,062,189$ & $19,252,865$ & $3,190,676$ & 19.86 \\
\hline 5 & 12 & Coffee & $342,551,929$ & $461,048,983$ & $118,497,054$ & 34.59 \\
\hline 6 & 16 & Other estate crops & $160,430,619$ & $112,964,193$ & $-47,466,426$ & -29.59 \\
\hline 7 & 17 & Other agriculture & $433,458,415$ & $359,359,003$ & $-74,099,412$ & -17.09 \\
\hline 8 & 18 & Livestock & $7,501,643$ & $8,811,600$ & $1,309,957$ & 17.46 \\
\hline 9 & 19 & Slaughtering & 35,500 & 86,845 & 51,345 & 144.63 \\
\hline 10 & 20 & Poultry and its product & $1,190,146$ & $1,802,911$ & 612,765 & 51.49 \\
\hline 11 & 21 & Wood & $14,035,128$ & $16,406,103$ & $2,370,975$ & 16.89 \\
\hline 12 & 22 & Other forest product & $157,010,713$ & $155,719,972$ & $-1,290,741$ & -0.82 \\
\hline 13 & 23 & Fishery & $614,200,056$ & $712,930,967$ & $98,730,911$ & 16.07 \\
\hline 14 & 24 & Coal and metal ore mining & $81,104,941$ & 32,050 & $-81,072,891$ & -99.96 \\
\hline 15 & 25 & $\begin{array}{l}\text { Crude oil, natural gas and geothermal } \\
\text { mining }\end{array}$ & $763,271,437$ & $214,550,070$ & $-548,721,367$ & -71.89 \\
\hline 16 & 26 & Other mining and quarrying & $276,535,197$ & $228,165,023$ & $-48,370,174$ & -17.49 \\
\hline 17 & 31 & Sugar factory & $15,041,601$ & $20,163,338$ & $5,121,737$ & 34.05 \\
\hline 18 & 32 & Manufacture of other food products & $85,530,356$ & $71,708,221$ & $-13,822,135$ & -16.16 \\
\hline 19 & 33 & Manufacture of beverages & 384,780 & $7,009,594$ & $6,624,814$ & $1,721.71$ \\
\hline 20 & 35 & Yarn spinning & $190,607,379$ & $198,455,762$ & $7,848,383$ & 4.12 \\
\hline 21 & 36 & $\begin{array}{l}\text { Manufacture of textile, wearing } \\
\text { apparel, and leather }\end{array}$ & $3,796,225,753$ & $3,355,888,548$ & $-440,337,205$ & -11.60 \\
\hline 22 & 37 & $\begin{array}{l}\text { Manufacture of bamboo, wood, and } \\
\text { rattan products }\end{array}$ & $196,769,114$ & $220,528,223$ & $23,759,109$ & 12.07 \\
\hline 23 & 38 & $\begin{array}{l}\text { Manufacture of paper, paper products, } \\
\text { and cardboard }\end{array}$ & $219,129,649$ & $231,369,788$ & $12,240,139$ & 5.59 \\
\hline 24 & 39 & Manufacture of fertilizer and pesticide & 188,024 & $102,120,551$ & $101,932,527$ & $54,212.51$ \\
\hline 25 & 40 & Manufacture of chemicals & $419,439,541$ & $367,971,025$ & $-51,468,516$ & -12.27 \\
\hline 26 & 42 & $\begin{array}{l}\text { Manufacture of rubber and plastic } \\
\text { wares }\end{array}$ & $2,954,082,555$ & $2,036,864,439$ & $-917,218,116$ & -31.05 \\
\hline 27 & 44 & Manufacture of cement & $9,285,024$ & $10,803,823$ & $1,518,799$ & 16.36 \\
\hline 28 & 45 & Manufacture of basic iron and steel & $148,077,980$ & $170,102,558$ & $22,024,578$ & 14.87 \\
\hline 29 & 47 & $\begin{array}{l}\text { Manufacture of fabricated metal } \\
\text { products }\end{array}$ & $24,340,457$ & $29,251,232$ & $4,910,775$ & 20.18 \\
\hline 30 & 48 & $\begin{array}{l}\text { Manufacture of machine, electrical } \\
\text { machinery, and apparatus }\end{array}$ & $1,454,743,939$ & $1,538,639,595$ & $83,895,656$ & 5.77 \\
\hline 31 & 49 & $\begin{array}{l}\text { Manufacture of transport equipment } \\
\text { and its repair }\end{array}$ & $62,389,621$ & $68,783,822$ & $6,394,201$ & 10.25 \\
\hline 32 & 50 & $\begin{array}{l}\text { Manufacture of other products not } \\
\text { elsewhere classified }\end{array}$ & $1,480,592,772$ & $1,696,114,428$ & $215,521,656$ & 14.56 \\
\hline TOT & & & $13,939,326,596$ & $12,436,589,954$ & $-1,502,736,642$ & -10.78 \\
\hline
\end{tabular}

Note. *ASEAN, China, Japan, and South Korea. Source: Statistics Indonesia and authors' calculation. 
Appendix 6. Export Growth to Asia*, EU and US by Input-Output Code (Jan-Oct 2011-2012)

\begin{tabular}{|c|c|c|c|c|c|c|}
\hline & & & Total (Asia, EL & and US) & Change & \\
\hline No. & $\begin{array}{l}\text { Input-Output } \\
\text { Code }\end{array}$ & Sector & 2011 & 2012 & US\$ & $\%$ \\
\hline 1 & 2 & Beans & $2,520,722$ & $8,707,818$ & $6,187,096$ & 245.45 \\
\hline 2 & 5 & Vegetables and fruits & $256,899,311$ & $198,371,200$ & $-58,528,111$ & -22.78 \\
\hline 3 & 6 & Other food crops & $176,733,577$ & $182,101,611$ & $5,368,034$ & 3.04 \\
\hline 4 & 11 & Tobacco & $470,760,524$ & $529,650,457$ & $58,889,933$ & 12.51 \\
\hline 5 & 12 & Coffee & $910,446,376$ & $1,112,240,333$ & $201,793,957$ & 22.16 \\
\hline 6 & 16 & Other estate crops & $856,743,384$ & $693,382,080$ & $-163,361,304$ & -19.07 \\
\hline 7 & 17 & Other agriculture & $7,984,617,694$ & $8,350,658,376$ & $366,040,682$ & 4.58 \\
\hline 8 & 18 & Livestock & $230,662,962$ & $208,906,928$ & $-21,756,034$ & -9.43 \\
\hline 9 & 19 & Slaughtering & $5,529,757$ & $4,715,771$ & $-813,986$ & -14.72 \\
\hline 10 & 20 & Poultry and its product & $7,769,185$ & $10,957,113$ & $3,187,928$ & 41.03 \\
\hline 11 & 21 & Wood & $36,306,735$ & $55,393,749$ & $19,087,014$ & 52.57 \\
\hline 12 & 22 & Other forest product & $179,950,912$ & $182,813,850$ & $2,862,938$ & 1.59 \\
\hline 13 & 23 & Fishery & $1,539,689,328$ & $1,849,016,031$ & $309,326,703$ & 20.09 \\
\hline 14 & 24 & Coal and metal ore mining & $5,009,725,306$ & $3,278,821,581$ & $-1,730,903,725$ & -34.55 \\
\hline 15 & 25 & $\begin{array}{l}\text { Crude oil, natural gas, and geothermal } \\
\text { mining }\end{array}$ & $44,884,771,703$ & $42,465,375,278$ & $-2,419,396,425$ & -5.39 \\
\hline 16 & 26 & Other mining and quarrying & $6,617,514,533$ & $4,608,841,095$ & $-2,008,673,438$ & -30.35 \\
\hline 17 & 31 & Sugar factory & $75,432,578$ & $91,326,236$ & $15,893,658$ & 21.07 \\
\hline 18 & 32 & Manufacture of other food products & $728,477,081$ & $841,429,811$ & $112,952,730$ & 15.51 \\
\hline 19 & 33 & Manufacture of beverages & $98,670,352$ & $71,047,475$ & $-27,622,877$ & -28.00 \\
\hline 20 & 35 & Yarn spinning & $1,834,154,813$ & $1,615,063,952$ & $-219,090,861$ & -11.95 \\
\hline 21 & 36 & $\begin{array}{l}\text { Manufacture of textile, wearing apparel, } \\
\text { and leather }\end{array}$ & $5,589,786,593$ & $5,276,304,667$ & $-313,481,926$ & -5.61 \\
\hline 22 & 37 & $\begin{array}{l}\text { Manufacture of bamboo, wood, and rattan } \\
\text { products }\end{array}$ & $1,878,048,960$ & $1,925,334,040$ & $47,285,080$ & 2.52 \\
\hline 23 & 38 & $\begin{array}{l}\text { Manufacture of paper, paper products, and } \\
\text { cardboard }\end{array}$ & $2,646,018,413$ & $2,640,511,691$ & $-5,506,722$ & -0.21 \\
\hline 24 & 39 & Manufacture of fertilizer and pesticide & $141,470,328$ & $206,746,226$ & $65,275,898$ & 46.14 \\
\hline 25 & 40 & Manufacture of chemicals & $7,374,403,991$ & $6,871,757,320$ & $-502,646,671$ & -6.82 \\
\hline 26 & 42 & Manufacture of rubber and plastic wares & $9,172,348,065$ & $6,553,869,099$ & $-2,618,478,966$ & -28.55 \\
\hline 27 & 44 & Manufacture of cement & $79,735,671$ & $73,762,508$ & $-5,973,163$ & -7.49 \\
\hline 28 & 45 & Manufacture of basic iron and steel & $1,711,641,555$ & $1,492,381,612$ & $-219,259,943$ & -12.81 \\
\hline 29 & 47 & Manufacture of fabricated metal products & $226,422,196$ & $189,320,968$ & $-37,101,228$ & -16.39 \\
\hline 30 & 48 & $\begin{array}{l}\text { Manufacture of machine, electrical } \\
\text { machinery, and apparatus }\end{array}$ & $10,332,403,152$ & $10,599,490,596$ & $267,087,444$ & 2.58 \\
\hline 31 & 49 & $\begin{array}{l}\text { Manufacture of transport equipment and } \\
\text { its repair }\end{array}$ & $2,658,094,645$ & $2,935,362,402$ & $277,267,757$ & 10.43 \\
\hline 32 & 50 & $\begin{array}{l}\text { Manufacture of other products not } \\
\text { elsewhere classified }\end{array}$ & $5,501,583,002$ & $5,898,594,428$ & $397,011,426$ & 7.22 \\
\hline TOTAL & & & $119,219,333,404$ & $111,022,256,302$ & $-8,197,077,102$ & -6.88 \\
\hline
\end{tabular}

Note. *ASEAN, China, Japan, and South Korea. Source: Statistics Indonesia and authors' calculation. 